\title{
Flora do Rio Grande do Norte, Brasil: Turneraceae Kunth ex DC.
}

\author{
Flora of Rio Grande do Norte, Brazil: Turneraceae Kunth ex DC.
}

\author{
Lamarck do Nascimento Galdino da Rocha ${ }^{1.4}$, José Iranildo Miranda de Melo² \& Ramiro Gustavo Valera Camacho ${ }^{3}$
}

\begin{abstract}
Resumo
Este trabalho consiste no levantamento da família Turneraceae no estado do Rio Grande do Norte, nordeste brasileiro. Foram registradas 13 espécies, distribuídas em dois gêneros: Piriqueta Aubl., com quatro espécies (P. duarteana (A. St.-Hil., A. Juss. \& Cambess.) Urb., P. guianensis N.E.Br., P. racemosa (Jacq.) Sweet e $P$. viscosa Griseb.), e Turnera L., com nove espécies (T. blanchetiana Urb., T. calyptrocarpa Urb., T. cearensis Urb., T. chamaedrifolia Cambess., T. diffusa Willd. ex Schult., T. melochioides A. St.-Hil. \& Cambess., T. pumilea L., T. scabra Millp. e T. subulata Sm.). São fornecidas chaves para separação de gêneros e espécies, descrições e ilustrações, além de comentários taxonômicos e biogeográficos para as espécies.

Palavras-chave: Caatinga, Piriqueta, taxonomia, Turnera, Rio Grande do Norte.
\end{abstract}

\begin{abstract}
This study comprises a survey of the family Turneraceae in the Rio Grande do Norte State, Northeastern Brazil. Two genera and 13 species were registered: Piriqueta Aubl., with four species (P. duarteana (A. St.Hil., A. Juss. \& Cambess.) Urb., P. guianensis N.E.Br., P. racemosa (Jacq.) Sweet and P. viscosa Griseb.), and Turnera, with nine species (T. blanchetiana Urb., T. calyptrocarpa Urb., T. cearensis Urb., T. chamaedrifolia Cambess., T. diffusa Willd. ex Schult., T. melochioides A. St.-Hil. \& Cambess., T. pumilea L., T. scabra Millsp. and T. subulata Sm.). Keys to genera and species, descriptions and ilustrations, and comments about taxonomy and biogeography of the species are presented.
\end{abstract}

Key words: Caatinga vegetation, Piriqueta, taxonomy, Turnera, Rio Grande do Norte state.

\section{Introdução}

A família Turneraceae Kunth ex DC. engloba doze gêneros e cerca de 220 espécies, distribuídas nas Américas e África, em Madagascar e Ilhas Mascarenhas (Arbo 2007, 2009; Thulin et al. 2012).

Embora Hutchinson (1973) tenha incluído Turneraceae em Loasales, tradicionalmente, a família se encontra na ordem Violales (Cronquist 1981; Dahlgren 1980). Turneraceae compartilha vários caracteres morfológicos e anatômicos com as famílias Malesherbiaceae e Passifloraceae sensu stricto, e as diversas análises apoiadas em sequências gênicas têm confirmado um forte parentesco entre elas (Chase et al. 2002). Segundo o Angiosperm Phylogeny Group III (APG III 2009), estas famílias formam o clado
Passifloraceae sensu lato, localizado na ordem Malpighiales. Neste estudo, entretanto, adotouse a circunscrição tradicional proposta por Cronquist (1981), em que Turneraceae ainda constitui uma família isolada de Passifloraceae e Malesherbiaceae.

No Brasil são encontrados os dois maiores gêneros da família, Piriqueta Aubl. e Turnera L., distribuídos em 155 espécies (destas 110 endêmicas), habitando os mais diversos ambientes (Arbo 2012).

Dentre os trabalhos propostos para Turneraceae, destacam-se os elaborados por Urban (1883a) e Arbo (1995a, 1997, 2000, 2005 e 2008). No Brasil, o tratamento clássico abordando a família foi publicado por Urban

\footnotetext{
${ }^{1}$ Universidade Estadual de Feira de Santana, Depto. Ciências Biológicas, Programa de Pós-Graduação em Botânica, C.P. 252 e 294, 44036-900, Feira de Santana, BA, Brasil.

${ }^{2}$ Universidade Estadual da Paraíba, Centro de Ciências Biológicas e da Saúde, Depto. Biologia, 58429-500, Campina Grande, PB, Brasil.

${ }^{3}$ Universidade do Estado do Rio Grande do Norte, Depto. Ciências Biológicas, 59610-090 Mossoró, RN, Brasil.

${ }^{4}$ Autor para correspondência: lamarck_rocha@hotmail.com
} 
(1883b) na Flora brasiliensis. Considerando-se o amplo espectro de distribuição geográfica de diversas espécies de Turneraceae no Brasil, as floras regionais são ainda escassas, destacandose os trabalhos de Moura (1975), Arbo (1998, 2006a, 2009) e Arbo \& Silva (2005). No que diz respeito ao Nordeste do Brasil, menções às espécies da família estão restritas a checklists e levantamentos florísticos, sendo os trabalhos de Arbo (1995b, 2006b) e Agra et al. (2009) os mais abrangentes.

Desta forma, objetivou-se estudar, do ponto de vista taxonômico, a família Turneraceae no estado do Rio Grande do Norte, de modo a atualizar a distribuição geográfica e evidenciar características morfológicas importantes para o reconhecimento dos gêneros e espécies da família na flora do estado.

\section{Material e Métodos}

O estado do Rio Grande do Norte apresenta área de $53.077,3 \mathrm{~km}^{2}$ e está situado no extremo nordeste brasileiro, entre os paralelos de $04^{\circ} 49^{\prime} 53^{\prime \prime}$ $06^{\circ} 58^{\prime} 03^{\prime \prime}$ 'S e os meridianos $35^{\circ} 58^{\prime} 03^{\prime \prime}-38^{\circ} 36^{\prime} 12^{\prime \prime}$ W. Limita-se com o oceano Atlântico ao Norte e a Leste, ao Sul com o estado da Paraíba e a Oeste com o estado do Ceará. Sua temperatura média anual é de $25,5^{\circ} \mathrm{C}$, com climas variando do Árido, Semi-Árido, Sub-Úmido Seco ao Clima Úmido (IDEMA, 2010). Compondo a vegetação do Estado, são encontradas as Caatingas (Hiperxerófila e Hipoxerófila e Seridó), Cerrados, Florestas (Caducifólia, Subcaducifólia, Subperenifólia e Estacional Mista Dicótilo-Palmácea), Vegetação de Dunas, Vegetação de Restinga, Formações rupestres, Campos (de várzea e antrópicos), Manguezais, Desertos Salinos, Capoeiras e Vegetação Aquática (SUDENE 1971).

As análises morfológicas e comparativas se fundamentaram nas coleções dos Herbários MOSS, UFRN e material coletado no estado, entre os anos 2008 e 2009. Acrônimos segundo Thiers (2012). O material obtido está depositado na coleção do Laboratório de Ecologia e Sistemática Vegetal, da Universidade do Estado do Rio Grande do Norte (LESV/UERN), ainda não indexada. As identificações foram realizadas com auxílio de literatura especializada e comparação com o material-tipo.

As descrições taxonômicas foram baseadas em espécimes coletados exclusivamente no estado do Rio Grande do Norte e a caracterização das estruturas vegetativas e reprodutivas se fundamentou nas terminologias propostas por Radford et al. (1974) e Harris \& Harris (1994), os tipos de indumento se basearam em Gonzalez \& Arbo (2004) e Payne (1978), e a venação em Hickey (1973). Os nomes dos autores foram consultados em Brumitt \& Powell (1992). O estado de conservação das espécies seguiu da União Internacional para a Conservação da Natureza e Recursos Naturais (IUCN 2001 e 2003).

\section{Resultados e Discussão}

No estado do Rio Grande do Norte foram encontradas 13 espécies distribuídas em dois gêneros; Piriqueta Aubl., com quatro espécies, e Turnera L., com nove. Ocorrem, preferencialmente, em ambientes abertos, na Caatinga e Restinga, inclusive associadas a locais perturbados pela ação antrópica.

Turneraceae Kunth ex DC., Prodr. 3: 345 (1828), nom. cons.

Ervas a subarbustos, anuais ou perenes, em geral tomentosas. Folhas alternas, simples, às vezes dispostas em rosetas apicais ou braquiblastos, serreado-crenadas a crenadas, com ou sem um par de nectários extraflorais, basilaminares; venação broquidódroma, estípulas pequenas ou ausentes. Inflorescência cimosa ou racemosa. Flores bissexuadas, actinomorfas, homostilas ou heterostilas, diclamídeas, 5-meras, pedúnculo livre ou soldado ao pecíolo, às vezes ausente; pedicelo desenvolvido ou não; sépalas 5 , quincunciais, unidas entre si, tubo 5-laciniado; pétalas 5 , contortas, livres ente si, unguiculadas, geralmente vistosas; corona as vezes presente, membranácea, anelar, fimbriado-lacerada, inserida na base da lâmina das pétalas e sob as sépalas; estames 5 , alternisépalos, livres, por vezes adnatos às pétalas pelas margens formando sacos nectaríferos, anteras ditecas, dorsifixas; ovário súpero, gamocarpelar, 3-carpelar, 1-locular, ovóide a globoso, tomentoso, óvulos geralmente muitos, anátropos, placentação parietal; estiletes 3 , livres entre si, terminais, estigmas fimbriados a ramosos. Fruto cápsula loculicida, 3-valvar, ovóide a globoso; sementes obovóides, retas ou curvas, tégmen reticulado; arilo membranáceo. 


\section{Chave para os gêneros de Turneraceae do Rio Grande do Norte}

1. Pedúnculo floral livre, pedicelo desenvolvido; brácteas e bractéolas ausentes; flores com corona membranácea, anelar, fimbriada, inserida na base da lâmina das pétalas e sob as sépalas; tricomas tectores simples, porrecto-estrelados, tricomas glandulares setiformes 1. Piriqueta

1'. Pedúnculo floral parcial ou totalmente adnato ao pecíolo, raro livre, pedicelo geralmente ausente; brácteas e bractéolas, presentes, localizadas na base das flores; corona ausente; tricomas tectores simples, estrelados, nunca porrecto-estrelados; tricomas glandulares capitados

2. Turnera

1. Piriqueta Aubl., Hist. Pl. Guiane 1: 298-300, pl. 117. 1775.

Subarbustos ou ervas perenes, raramente anuais, pouco ramificadas, indumento tomentoso a hirsuto, tricomas glandulares setiformes de base dilatada, e tectores simples, estrelados, porrectoestrelados de raio central bem desenvolvido. Folhas sem estípulas, nectários ausentes. Inflorescências unifloras, axilares, cimosas ou reunidas em racemos terminais, pedúnculo desenvolvido, livre, geralmente sem brácteas e bractéolas. Flores homostilas ou heterostilas; pedicelo desenvolvido. Cálice parcialmente gamossépalo, obcônico a campanulado. Corola branca, amarela, salmão à rosada, pétalas obovadas, unguiculadas; corona membranácea fimbriada, inserida na base da lâmina das pétalas e sob as sépalas. Estames livres entre si, base adnata ao tubo floral, anteras ovadas, ápice geralmente curvo. Ovário tomentoso, estiletes filiformes, estigmas fimbriados. Cápsulas estrigosas, lisas ou verrucosas. Sementes obovoides, malhas do retículo proeminentes ou não, arilo unilateral.

Piriqueta inclui 44 espécies, restritas ao continente americano (Thulin et al. 2012). Ocorre desde o sul dos Estados Unidos até o norte da Argentina (Arbo 2009). Para o Brasil são referenciadas 37 espécies, 25 das quais endêmicas, com centro de diversidade na Bahia (Arbo 2012; Arbo \& Silva 2005). Distribuem-se no cerrado, campos, campos rupestres e em caatinga (Arbo \& Mazza 2011). No estado do Rio Grande do Norte foram registradas quatro espécies, comumente associadas à ambientes de caatinga e restinga.

\section{Chave para as espécies de Piriqueta do Rio Grande do Norte}

1. Flores em racemos terminais; pétalas brancas ou amarelas; frutos lisos; sementes marcadamente curvas, malhas do retículo proeminentes 3. P. racemosa

1'. Flores solitárias, axilares, nunca em racemos terminais; pétalas de outras cores; frutos verrucosos; sementes ligeiramente curvas, malhas do retículo não proeminentes.

2. Flores homostilas; pétalas rosadas 1.4. P. viscosa

2'. Flores heterostilas; pétalas salmão.

3. Frutos com tricomas glandulares setiformes de base negra; pedúnculo frutífero $2-10 \mathrm{~mm}$ compr. 1.1. P. duarteana

3'. Frutos sem tricomas glandulares setiformes de base negra; pedúnculo frutífero 10-34 mm compr. 1.2. P. guianensis

1.1. Piriqueta duarteana (A. St.-Hil., A. Juss. \& Cambess.) Urb. Jahrb. Königl. Bot. Gart. Berlin 2: 66. 1883 .

Fig. 1a

Ervas, ca. $50 \mathrm{~cm}$ alt.; ramos tomentosos, tricomas tectores simples, porreto-estrelados, estrelados, e glandulares setiformes. Folhas cartáceas; pecíolo 1-6 mm compr.; estípulas ausentes; lâmina 1-34 × 6-19 mm, ovada, ápice agudo, margens serreado-crenadas, revolutas, base cuneada. Inflorescências unifloras, pedúnculo 2-10 mm compr. Flores heterostilas; pedicelo 1-2 mm compr. Tubo calicino ca. $2 \mathrm{~mm}$ compr., lacínios 4-8 mm compr., externamente tomentosos. Corola ca. $15 \mathrm{~mm}$ compr., salmão, fauce amarela; corona $0,5-1,2 \mathrm{~mm}$, fimbriada, escura em seco. Estames glabros; filetes ca. $4,5 \mathrm{~mm}$ compr. em flores longistilas; anteras $1,5 \mathrm{~mm}$ compr. Ovário ca. $2 \mathrm{~mm}$ compr., ovóide, tomentoso, estiletes 


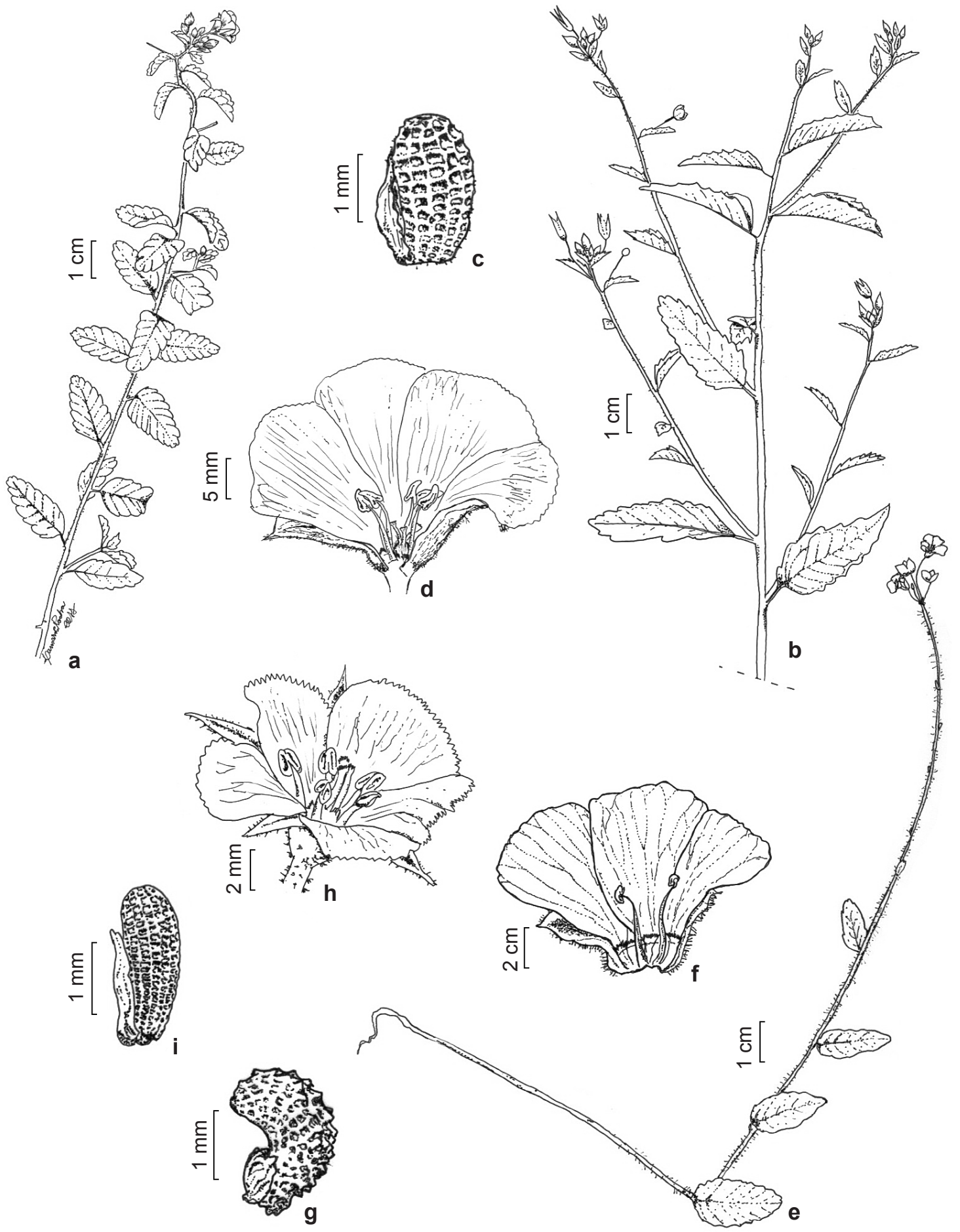

Figura 1 - a. Piriqueta duarteana (O.F. Oliveira 455) - ramo florífero. b-d. P. guianensis (L.N.G. Rocha 127) - b. ramo florífero; c. flor brevistila; d. semente. e-g. P. racemosa (L.N.G. Rocha 21) - e. ramo florífero; f. flor dissecada evidenciando os estames e corona (flor homostila); g. semente. h-i. P. viscosa (J.I.M. Melo 822) - h. flor homostila; i. semente.

Figure 1 - a. Piriqueta duarteana (O.F. Oliveira 455) - fertile branch. b-d. P. guianensis (L.N.G. Rocha 127) - b. fertile branch; c. flower brevistylous; d. seed. e-g. P. racemosa (L.N.G. Rocha 21) - e. fertile branch; f. dissected flower showing stamens and corona (flower homostylous); g. seed. h-i. P. viscosa (J.I.M. Melo 822) - h. flower homostylous; i. seed. 
ca. $6 \mathrm{~mm}$ compr. em flores longistilas, glabros, estigmas ramosos. Cápsulas 5-10 mm diâm., globosas, verrucosas, tomentosas, tricomas simples e glandulares setiformes de base negra. Sementes ca. 2,5 mm compr., retas a curvas, tégmen com malhas não proeminentes, testa puberulenta; arilo $1,5-2 \mathrm{~mm}$ compr.

Material examinado: Mossoró, Serra do Carmo, 3.X.1973, fl. e fr., O.F. Oliveira 455 (MOSS). Natal, próximo a via costeira e Morro de Mãe Luíza, 30.IX.1980, fl. e fr, O.F. Oliveira et al. 1335 (MOSS).

Piriqueta duarteana é endêmica do Brasil, ocorre nos estados do Pará, Tocantins, Mato Grosso, Goiás, Minas Gerais e todos estados do Nordeste (Arbo 2012). Na área de estudo está associada à vegetação de caatinga. Encontrada com flores e frutos nos meses de outubro e novembro. Enquadra-se na categoria "Não Ameaçada de Extinção" (LC).

Integra um complexo de espécies morfologicamente relacionadas, e apresenta duas variedades: Piriqueta duarteana var. duarteana e $P$. duarteana var. ulei, que se diferenciam pelo indumento e pelos frutos (Arbo 1995a). Somente a variedade típica foi registrada para o estado do Rio Grande do Norte. Assemelha-se morfologicamente à $P$. guianensis, da qual pode ser diferenciada pela presença de pedúnculos florais pouco desenvolvidos, sementes menores, mas principalmente pelos tricomas glandulares de base enegrecida nos frutos. Arbo (1995) cita a ocorrência de flores brevistilas para a espécie, porém, neste estudo foram analisadas somente flores longistilas.

1.2. Piriqueta guianensis N.E.Br. Trans. Linn. Soc. London, Bot. 6 (1): 30. 1901 [1901-05 publ. Jan 1901].

Fig. 1b-d

Ervas, perenes, 0,3-1,2 $\mathrm{m}$ alt.; ramos tomentosos, tricomas tectores simples e curtos, porreto-estrelados, raio central ca. $1 \mathrm{~mm}$ compr., as vezes glandulares, setiformes. Folhas cartáceas; pecíolo 1-6 mm compr.; estípulas ausentes; lâmina $3-54 \times 1,5-18(23) \mathrm{mm}$, ovada a lanceolada, ápice agudo a obtuso, margem serreado-crenada, ligeiramente revoluta, base cuneada. Inflorescências unifloras, axilares; pedúnculo 10-34 mm compr. Flores heterostilas; pedicelo 3-14 mm compr. Tubo calicino 2-3,5 mm compr., lacínios 4-11 mm compr., externamente tomentosos. Corola 11-24 mm compr., salmão, fauce amarelo-viva ou púrpura; corona 0,8-2 mm compr., fimbriada, escura em seco. Estames glabros; filetes 7,5-9 mm compr. em flores brevistilas, 5-7,7 mm compr. em flores longistilas; anteras ca. $2 \mathrm{~mm}$ compr. Ovário 3-2,5 mm compr., ovóide, tomentoso, estiletes ca. $2 \mathrm{~mm}$ compr. em flores brevistilas, e ca. $7 \mathrm{~mm}$ compr.em longistilas, raros tricomas simples, estigmas fimbriados. Cápsulas 6-9 mm diâm., globosas, verrucosas, tricomas simples e glandulares setiformes. Sementes ca 1,9 mm compr., obovóides, retas, tégmen com malhas não proeminentes; arilo 1,5-1,9 $\mathrm{mm}$ compr.

Material examinado: Assú, Floresta Nacional de Assú, 19.X.2008, fl. e fr., D.N.N. Souza \& N.F.I. Silva 09 (UERN). Baia Formosa, Praia do Sagi, 2.XI.2007, fl. e fr., R.C. Oliveira 1993 (MOSS). Jandaíra, Estação Ecológica de Terras Secas, 15.IV.1986, S.H. Vasconcelos 12 (MOSS). Jardim de Piranhas, Fazenda Sobrado, 8.IV.1981, fl. e fr., G.F.C. Lima 69 (MOSS). Jucurutu, RPPN Stöessel de Brito, 28.III.2009, fr. e fr., L.N.G. Rocha 127 (UERN). Macaíba, 10.VII.1994, fl. e fr., G.G.C. Silva \& M.S.F. Melo 02 (MOSS). Mossoró, Suçuarana, 25.IV.1997, fl. e fr., K.D. Nogueira 07 (MOSS). Natal, Parque da Cidade, 28.IV.2007, V.R.R. Sena et al. 79 (UFRN). Nísia Floresta, 30.III.2008, fl. e fr., F.S.R. Sousa \& M.R.O. Trindade 15 (UFRN). Serra do Mel, 05¹0'12”S, 3701'46”W, 3.V.2008, fl. e fr., J.I.M. Melo (MOSS 10170). Serra Negra do Norte, Estação Ecológica do Seridó, 23.VI.2006, fl., C.G.T. Ferreira \& G.S. Araújo 191 (MOSS). Tibau, Dunas das Areias Alvas, 7.X.2005, fl., R.C. Oliveira 1578 (MOSS).

De acordo com Arbo (2012), Piriqueta guianensis se distribui no Norte (Roraima) e Nordeste (Alagoas, Bahia, Ceará, Paraíba, Pernambuco, Piauí, Rio Grande do Norte e Sergipe). $\mathrm{Na}$ área de estudo ocorre na restinga e caatinga. Floresce e frutifica praticamente durante todo o ano. Enquadra-se na categoria "Não Ameaçada de Extinção" (LC).

Compõe o complexo de P. duarteana, sendo morfologicamente semelhantes. P. guianensis caracteriza-se, principalmente, pelos pedúnculos florais bem desenvolvidos, folhas adultas com 4-6 pares de veias laterais, e frutos sem tricomas setiformes de base negra, $P$. duarteana apresenta pedúnculos florais mais curtos, folhas adultas com 7-8 pares de veias laterais e frutos com tricomas setiformes de base negra (Arbo 1995a).

Arbo (1995a) reconhece duas subespécies: P. guianensis subsp. guianensis N.E.Br. e $P$. guianensis N.E.Br. subsp. elongata (Urban et Rolfe) Arbo, onde a primeira apresenta nervuras laterais com ângulo de divergência de $22-45^{\circ}$, estiletes pilosos, lâmina foliar ligeiramente revoluta e sementes com 1,5-1,8 mm compr.; já as nervuras da segunda subespécie elongata divergem em $18-30^{\circ}$, os estiletes são glabros, 
lâmina foliar é plana e suas sementes têm 1,9-2,3 $\mathrm{mm}$ compr. Nos espécimes examinados foram observados caracteres descritos para as duas subespécies, como os estiletes com tricomas simples (caráter descrito para $P$. guianensis subsp. guianensis) e comprimento da semente $1,9 \mathrm{~mm}$ compr., característica de $P$. guianensis subsp. elongata. Desta forma, optou-se por não admitir as subespécies propostas pela autora, haja vista a sobreposição observada nos caracteres adotados para a diferenciação das mesmas com aqueles visualizados nos espécimes examinados.

\subsection{Piriqueta racemosa (Jacq.) Sweet, Hort. Brit.} [Sweet] 154. 1826.

Fig. 1e-g

Ervas, ca. $40 \mathrm{~cm}$ alt., anuais ou perenes; ramos hirsutos, tricomas tectores simples e crespos, porrecto-estrelados, raio central ca. $4 \mathrm{~mm}$ compr. Folhas papiráceas; pecíolo $0-15 \mathrm{~mm}$ compr.; lâmina 11-60 × 4-37 mm, diminuindo bruscamente em direção ao ápice dos ramos, ovada a ovadoelíptica, ápice agudo, por vezes, obtuso, margem serreado-crenada, discretamente revoluta, base cuneada a arredondada. Inflorescências racemosas; pedúnculo 25-40 $\mathrm{mm}$ compr. Flores mediostilas; pedicelo 1-4 mm compr. Tubo calicino 1-2,5 $\mathrm{mm}$ compr., lacínios 3-8 mm compr., hirsutos, múcron apical ca. $4 \mathrm{~mm}$ compr. Corola $6-9 \mathrm{~mm}$ compr., alva a amarelada, fauce amarelo intenso; corona $0,5-0,9 \mathrm{~mm}$ compr., amarelada em vivo. Estames glabros a pubescentes; filetes ca. $4 \mathrm{~mm}$ compr.; anteras ca. 1,5 mm compr. Ovário 2,5-3,5 $\mathrm{mm}$ compr., tomentoso, globoso, estiletes $2-2,3 \mathrm{~mm}$ compr., estigmas ramosos. Cápsulas 5,3-11 mm diâm., subglobosas, lisas, pubescentes. Sementes ca. $2 \mathrm{~mm}$ compr., obovoides, marcadamente curvas, malhas do tégmen proeminentes, castanho-escura; arilo $0,8-1 \mathrm{~mm}$ compr.

Material selecionado: Apodi, Assentamento Moacir Lucena, 29.IV.2008, fl. e fr., J.I.M. Melo et al. 706 (UERN). Felipe Guerra, Comunidade Mulungu, 05.IV.2008, fl., R.C. Oliveira et al. 2103 (B) (MOSS). Jandaíra, Estação Ecológica de Terras Secas, 13.V.1986, S.H. Vasconcelos 10 (MOSS). Marcelino Vieira, Sítio Pitombeira, 15.IV.2008, fl. e fr., L.N.G. Rocha 21 (UERN). Mossoró, BR 110, 7.V.2009, fl. e fr., A.F.A. Maia 01 (UERN). Patú, Serra do Lima, 19.IV.2009, fl., J.I.M. Melo et al. 823 (UERN). Serra Negra do Norte, Estação Ecológica do Seridó, 14.IV.2006, fl. e fr., R.T. Queiroz 660 (UFRN).

Ocorre nas Antilhas, Colômbia, Venezuela, Paraguai e Brasil (Arbo 1995a, 2012). Neste trabalho, é registrada pela primeira vez para o estado do Rio Grande do Norte sendo comumente encontrada na caatinga, por vezes habitando locais modificados. Coletada com flores e frutos nos meses de abril e maio. Enquadra-se na categoria "Não Ameaçada de Extinção" (LC).

Foram observadas somente flores mediostilas, muito embora Arbo (1995a) cite a ocorrência de heterostilia do tipo tristilia para a espécie, podendo ainda ser encontradas flores longistilas e brevistilas. Pode ser facilmente reconhecida pelo caule hirsuto, inflorescências em racemos alongados ou, ainda, pelos frutos lisos e sementes marcadamente curvas e com malhas do tégmen proeminentes.

1.4. Piriqueta viscosa Griseb. Cat. Pl. Cub. [Grisebach] 114. 1866.

Fig. 1h-i

Ervas, ca. $70 \mathrm{~cm}$ alt., anuais ou perenes; ramos tomentosos, viscosos, tricomas tectores simples e crespos, porrecto-estrelados, e glandulares setiformes, ferrugíneos. Folhas papiráceas; pecíolo 1-6 mm compr.; lâmina 26-66 × 6-24 mm, ovada, estreito-ovada a lanceolada, ligeiramente reflexa, ápice agudo, margem serreado-crenada, base cuneada. Inflorescências unifloras, axilares, pedúnculo 4-12 mm compr. Flores homostilas; pedicelo 5-12 mm compr. Tubo calicino ca. 2,5 $\mathrm{mm}$ compr., lacínios 4,5-6 $\mathrm{mm}$, externamente tomentosos, múcron apical 1,5 mm compr. Corola 6-20 mm compr., rosada, fauce purpúrea, ápice discretamente denteado; corona $0,5 \mathrm{~mm}$ compr., escura em seco. Estames glabros; filetes $3,5 \mathrm{~mm}$ compr.; anteras ca. $1 \mathrm{~mm}$ compr., retas. Ovário 2 $\mathrm{mm}$ compr., ovóide, tomentoso, estiletes $2,5 \mathrm{~mm}$ compr., estigmas fimbriados. Cápsulas ca. $7 \mathrm{~mm}$ diâm., ovadas a globosas, verrucosas, tomentosas. Sementes ca. $2 \mathrm{~mm}$ compr., obovoides, retas, castanho-escura; arilo 1,1-1,7 mm compr.

Material examinado: Mossoró, Margem da BR 304, 1.VI.1979, fl., O.F. Oliveira 731 (MOSS). Patú, Serra do Lima, 19.VI.2009, f1. e fr., J.I.M. Melo 822 (UERN).

Distribui-se nas Antilhas, Mesoamérica e América do Sul, desde a Colômbia e Venezuela até o Brasil, onde se dispersa até o estado de Mato Grosso do Sul (Arbo 1995a, 2012). Neste estudo, o estado do Rio Grande do Norte é acrescentado à sua distribuição. Encontrada na caatinga, em áreas abertas. Coletada com flores e frutos em abril e junho. Enquadra-se na categoria "Não Ameaçada de Extinção" (LC).

Arbo (1995a) reconhece duas subespécies para Piriqueta viscosa: P. viscosa Gribeb. subsp. viscosa Urb. e P. viscosa Griseb. subsp. tovarensis 
Urb. Neste trabalho foi tratada $P$. viscosa Griseb. subsp. viscosa Urb., facilmente reconhecida por apresentar ramos viscosos, flores de corola rosada e pedúnculos florais bem desenvolvidos.

\section{Turnera L. Sp. Pl. 1: 271. 1753.}

Ervas a subarbustos, anuais ou perenes; pouco ou muito ramificadas, pilosos. Folhas com ou sem nectários, com duas estípulas, às vezes reduzidas a coléteres. Inflorescência uniflora ou pluriflora, axilares, cimosas ou secundariamente racemosas, capituliformes, pedúnculo livre ou adnato ao pecíolo (flor epífila), brácteas e/ou bractéolas geralmente inseridas próximo da base do cálice. Flores heterostilas ou homostilas; pedicelo não desenvolvido. Cálice parcialmente gamossépalo, obcônico a campanulado. Corola branca a amarela, pétalas obovadas, unguiculadas, sem corona. Estames com filetes com face adaxial adnata parcialmente à base do tubo floral, às vezes com margens adnatas à unha das pétalas formando sacos nectaríferos; anteras ovadas. Ovário ovóide a globoso, estiletes filiformes, estigmas fimbriados a ramosos. Cápsulas verrucosas ou lisas, tomentosas, pubescentes ou puberulentas. Sementes com tégmen reticulado, calaza proeminente ou não, testa pubescente, lisa ou papilosa; arilo unilateral ou envolvente.

Turnera foi organizado por Urban (1883a) em nove séries: Salicifoliae Urb., Stenodictyae Urb., Annulares Urb., Capitatae Urb., Microphyllae Urb., Papilliferae Urb., Leiocarpae Urb., Anomalae Urb. e Turnera Urb. Mais recentemente Arbo (2008) propôs duas outras séries: Conciliatae Arbo e Sessilifoliae Arbo. Atualmente este gênero engloba 140 espécies, distribuem-se desde os Estados Unidos até a Argentina e África, onde ocorrem somente duas espécies (Arbo \& Mazza 2011). No estado do Rio Grande do Norte foram registradas nove espécies; algumas delas apresentando potencial medicinal (Braga 2001).

\section{Chaves para as espécies de Turnera do Rio Grande do Norte}

1. Frutos lisos.

2. Flores heterostilas em inflorescências globosas capituliformes; sépalas pubescentes; pétalas ca. $17 \mathrm{~mm}$ compr.; ovário e frutos inteiramente tomentosos 2.6. T. melochioides

2'. Flores homostilas, axilares ou em rosetas apicais, tomentosas; tubo calicino glabro ou com raros tricomas; pétalas ca. $7 \mathrm{~mm}$ compr.; base do ovário e do fruto glabros estes com tricomas adensados na porção apical

2.7. T. pumilea

1' Frutos verrucosos.

3. Filetes com face adaxial das margens adnatas às unhas das pétalas, formando sacos nectaríferos.

4. Ramos aromáticos, flores e frutos com tricomas estrelados.

5. Flores isoladas

2.3.T. cearensis

5'. Flores em inflorescências secundariamente racemosas, capituliformes

2.1.T. blanchetiana

4'. Ramos, flores e frutos com tricomas simples.

6. Pétalas alvas, raro amareladas, fauce enegrecida

2.9. T. subulata

6'. Pétalas amarelas, fauce amarelo intenso

2.8. T. scabra

3'. Filetes adnatos parcialmente pela face adaxial à base do tubo floral, mas nunca formando sacos nectaríferos.

7. Tricomas capitados estipitados; flores creme, quando secas

2.4. T. chamaedrifolia

7'. Tricomas capitados sésseis; flores amareladas a alvas, mesmo quando secas.

8. Estípulas 0,5-1 mm compr. Brácteolas subuladas; pétalas ca. $9 \mathrm{~mm}$ compr., amareloouro …...................................................................................... 2.5.T. diffusa

8.' Estípulas 1,5-4,9 mm compr. Brácteolas obovadas; pétalas ca. 8-10,2 mm compr., brancas, fauce amarelo-vivo 2.2.T. calyptrocarpa

2.1. Turnera blanchetiana Urb., Jahrb. Königl. Bot. Gart. Berlin 2: 130. $1883 . \quad$ Fig. 2a-d

Arbustos, ca. 2,3 m alt.; tomentosas, tricomas tectores estrelados, principalmente nos ramos jovens, lenticelados. Folhas cartáceas; pecíolo 2-8 mm compr.; estípulas ca. $2 \mathrm{~mm}$ compr., lineares; lâmina 1,4-4,8 × 0,9-2,9 cm, elíptica, ovada a obovada, ápice agudo a obtuso, margem 

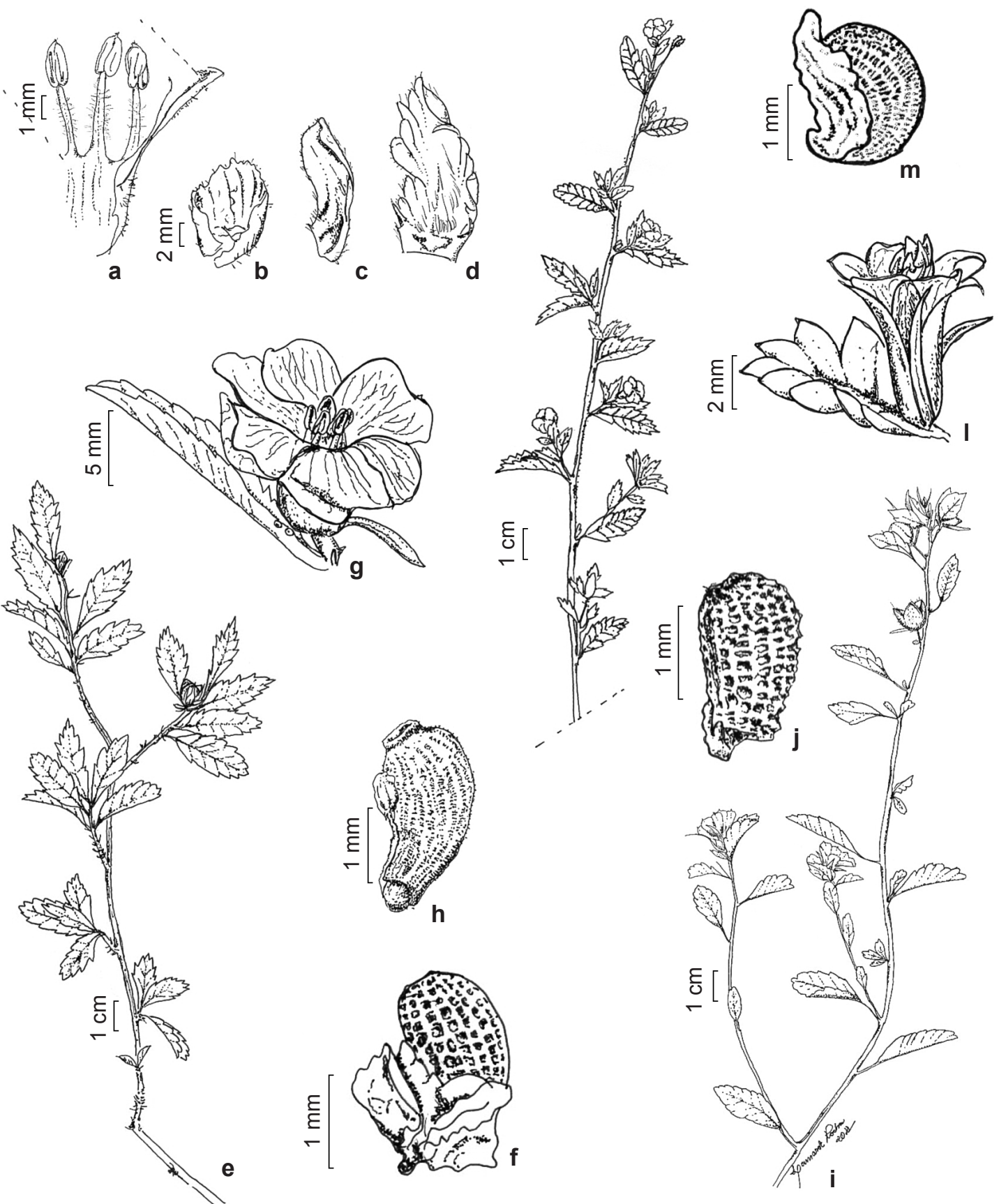

Figura 2 - a-d. Turnera blanchetiana (I.N.G. Rocha 294) - a. estames evidenciando as margens adnatas; b. bráctea inferior; c-d. bracteolas. e-f. T. calyptrocarpa (I.N.G. Rocha 293) - e. ramo frutífero; f. semente. g-h. T. cearensis (I.N.G. Rocha 259) - g. flor brevistila; h. semente. i-j. T. chamaedrifolia (O.F. Oliveira 1577) - i. ramo florífero; j. semente. k-m. T. diffusa (G.B.C. Paterno \& M.I.B. Loiola 160) - k. ramo florífero; 1. flor brevistila; m. semente. Figure 2 - a-d. Turnera blanchetiana (I.N.G. Rocha 294) - a. stamens showing adnated margin; b. lower bract; c-d. bracteoles. e-f. T. calyptrocarpa (I.N.G. Rocha 293) - e. fruit branch; f. Seed. g-h. T. cearensis (I.N.G. Rocha 259) - g. flower brevistylous; h.seed. i-j. T. chamaedrifolia (O.F. Oliveira 1577) - f. fertile branch; g. seed. k-m. T. diffusa (G.B.C. Paterno \& M.I.B. Loiola 160) - k. fertile branch; 1. flower brevistylous; m. seed. 
crenada a crenado-serreada, base cuneada a atenuada; nectários 2-0,6 mm diâm., basilaminares. Inflorescências secundariamente racemosas, capituliformes, globosas; pedúnculo 2-4 mm compr. Flores heterostilas; sésseis; bráctea 5,5-7 mm compr., ovada; bractéolas 2, 4-9 mm compr., estreito-ovadas, localizadas na base das flores. Tubo calicino 4-10 mm compr., lacínios 3-5 mm compr., externamente tomentosos. Corola 11-15 mm compr., totalmente amarela. Estames pubescentes; filetes ca. $4 \mathrm{~mm}$ compr. em flores longistilas, ca. 7,5 mm compr. em flores brevistilas, adnatos por suas margens a unha das pétalas; anteras 1,5-2 mm compr., retas, apiculadas, ápice pubescente. Ovário 2,5-3,5 mm compr., ovóide, tomentoso, estiletes $4 \mathrm{~mm}$ compr. em flores longistilas, $2 \mathrm{~mm}$ compr. em flores brevistilas, com poucos tricomas na base, estigmas ramosos. Cápsulas 5-9 mm diâm., subglobosas, verrucosas, tomentoso, revestido por restos florais. Sementes 2,2-3,3 mm compr., obovoides, tégmen estriado reticulado, malhas não proeminentes, testa papilosa; arilo mais largo ou mais curto que a semente.

Material selecionado: Mossoró, Suçuarana, 12.III.2011, fl., L.N.G. Rocha 294 (UERN).

Turnera blanchetiana possui duas variedades, var. blanchetiana Urb. e var. subspicata Urb. No estado do Rio Grande do Norte ocorre somente a variedade típica, que ocorre apenas no Brasil, nos estados da Bahia, Ceará, Paraíba, Pernambuco, Piauí alcançando o norte de Minas Gerais (Arbo 2012). Na área de estudo ocorre em vegetação de caatinga, associada a substratos argilosos. Coletada com flores em março. Enquadra-se na categoria "Não Ameaçada de Extinção" (LC).

A espécie apresenta hábito semelhante ao de $T$. cearensis, entretanto, esta última possui inflorescências unifloras, com brácteas, e tricomas mais longos em toda a planta. As informações referentes aos frutos e sementes se basearam em Arbo (2005).

2.2. Turnera calyptrocarpa Urb., Jahrb. Königl. Bot. Gart. Berlin 2: 128. 1883.

Fig. 2e-f

Arbustos ca. 1,5 m alt.; estrigosos, tricomas tectores simples ondulados e glandulares capitadosésseis; cicatrizes foliares proeminentes; lenticelas inconspícuas. Folhas cartáceas, adensadas no ápice de braquiblastos; pecíolo 1-4 mm compr.; estípulas 1,5-4,9 mm compr.; lâmina 7-22 × 3-10 $\mathrm{mm}$, obovada a oblongo-ovada, ápice obtuso, margem serreado-crenada, revoluta, base atenuada; nectários extraflorais ausentes. Inflorescências unifloras, congestas no ápice dos braquiblastos. Flores heterostilas, brácteolas 3-7 × 0,1-2,3 mm, estipuladas, estípulas ca. 0,5 mm compr. Tubo calicino 3-8 mm compr., lacínios 2-5 mm compr., externamente pilosos. Corola 8-10 mm compr., alva, fauce amarelo-viva. Estames pubescentes até a porção média; filetes ca. $8 \mathrm{~mm}$ compr. em flores brevistilas, 3,5-4 mm compr. em flores longistilas; anteras 1,5-2 mm compr., ápice reto a curvo, apiculadas. Ovário ca. 2,5 mm compr., ovóide, tomentoso; estiletes ca. $2 \mathrm{~mm}$ compr., em flores brevistilas, 2-5 mm compr. em flores longistilas, porção média puberulenta, estigmas ramosos. Cápsulas 3-6,2 mm diâm., ovóides, verrucosas, estrigosas, revestidas por restos florais. Sementes ca. $2 \mathrm{~mm}$ compr., obovóides, ligeiramente curvas, malhas do tégmen não proeminentes; arilo $1,7 \mathrm{~mm}$ compr., lacerado.

Material examinado: Mossoró, Suçuarana, 12.III.2011, fl. e fr., L.N.G. Rocha 293 (UERN). Parnamirim, EMPARN, Mata do Jiquí, 28.XI.2007, fl. e fr., A.C.P. Oliveira et al. 781 (UFRN). São Vicente, 1.III.1980, fl., O.F. Oliveira et al. 146 (MOSS).

Turnera calyptrocarpa ocorre no Piauí, Ceará, Paraíba, Pernambuco, Bahia, Sergipe e Minas Gerais (Arbo 2012). Constitui, neste trabalho, uma nova ocorrência para o estado do Rio Grande do Norte. Foi encontrada em ambientes de restinga e caatinga. Coletada com flores e frutos nos meses de março e novembro. Enquadra-se na categoria "Não Ameaçada de Extinção" (LC).

Assemelha-se morfologicamente a T. diffusa Willd. ex Schuld. var. diffusa, sendo facilmente diferenciada pelas brácteolas obovadas, bem como pelas pétalas alvas com fauce amarelada, e as estípulas longas.

2.3. Turnera cearensis Urb., Jahrb. Königl. Bot. Gart. Berlin 2: 100. 1883. Fig. 2g-h

Ervas perenes ou arbustos, 0,4-1,5 m alt.; estrigosos a tomentos, tricomas tectores simples, lisos ou crespos, e estrelados de raios longos; lenticelas 0,5-2 mm diâm.; cicatrizes foliares proeminentes. Folhas cartáceas; pecíolo 1-10 mm compr.; estípulas 1-4 mm compr.; lâmina 17-65 × 6-30 mm, ovada a ovado-elíptica, ápice agudo, raro obtuso, margem serreado-crenada a marcadamente crenada, base cuneada a arredondada, revoluta; nectários extraflorais 2, ca. 0,4 mm diâm., discóides. Inflorescência uniflora, axilar. Flores heterostilas; pedúnculo ca. $4 \mathrm{~mm}$ compr.; livre do pecíolo; pedicelo ausente; brácteas $4-8 \times 0,8-1,5 \mathrm{~mm}$, 
obovadas a obovado-lanceoladas. Tubo calicino 9,5-10,4 mm compr., lacínios ca. $7 \mathrm{~mm}$ compr., múcron ca. 0,5 mm compr. Corola ca. $11 \mathrm{~mm}$ compr., amarelo-viva. Estames pubescentes; filetes $8 \mathrm{~mm}$ compr.em flores longistilas; anteras ca. 2 $\mathrm{mm}$ compr., ápice reto. Ovário ovóide, tomentoso; estiletes $6-8 \mathrm{~mm}$ compr. em flores longistilas, pubescentes, estigmas penicilados. Cápsulas ca. $6 \mathrm{~mm}$ diâm., globosas, verrucosas, tomentosas, tricomas adensados no ápice das valvas. Sementes obovoides 2,7-3 mm compr., curvas, tégmen com malhas longitudinais proeminentes; arilo ca. $2 \mathrm{~mm}$ compr., lacerado.

Material examinado: Cerro Corá, 29.II.1980, fl. e fr., O.F. Oliveira et al. 103 (MOSS). Florânia, Sítio Cajueiro, 14.II.1981, fl. e fr., O.F. Oliveira et al. 1634 (MOSS). Martins, Mirante, 15.X.2009, fl., L.N.G. Rocha 259 (UERN). Patú, Serra do Lima, 30.I.2008, fl., J.I.M. Melo et al. 664 (UERN). São Vicente, Saco de Santa Cruz, 12.II.1994, fl. e fr., O.F. Oliveira 156 (MOSS). Serra Negra do Norte, Estação Ecológica do Seridó, 17.IV.2006, fl., R.T. Queiroz 756 (UFRN).

Turnera cearensis ocorre somente no Brasil, descrita para o Maranhão, Ceará, Rio Grande do Norte, Paraíba, Pernambuco, Bahia, Alagoas, Sergipe, Minas Gerais (Arbo 2012). No Rio Grande do Norte foi encontrada na caatinga; com flores e frutos nos meses de janeiro, fevereiro, abril e outubro. Cresce em solos arenosos bem drenados. Enquadra-se na categoria "Não Ameaçada de Extinção" (LC).

Assemelha-se morfologicamente à espécie $T$. blanchetiana, porém, esta última se distingue por apresentar inflorescências globosas, capituliformes, e tricomas estrelados, muito curtos.

2.4. Turnera chamaedrifolia Cambess., Fl. Bras. Merid. (4.ed.) 2: 221. $1830 . \quad$ Fig. 2i-j

Subarbustos, ca. $70 \mathrm{~cm}$ atl.; ramos pubescentes a tomentosos, tricomas tectores simples, e tricomas glandulares, capitado-estipitados; cicatrizes foliares salientes. Folhas cartáceas; pecíolo 2,5-10 mm compr.; estípulas inconspícuas; lâmina 7-70 $\times 5-32 \mathrm{~mm}$, discolor, ovada a ovado-elíptica, raro obovada, margem serreado-crenada, discretamente revoluta, base atenuada à cuneada, nectários extraflorais ausentes. Inflorescências unifloras, axilares. Flores heterostilas; pedúnculo $6-10 \mathrm{~mm}$ compr., livre; pedicelo ausente; brácteolas $1,1-0,8 \times$ $0,5-1 \mathrm{~mm}$, lineares a subuladas. Tubo calicino ca. 2 mm compr., lacínios 7-8 mm compr., externamente hirsutos. Corola 13-16 mm compr., amarela a creme. Estames glabros; filetes ca. 4,5 mm compr. em flores longistilas, livres, face adaxial adnata à base do tubo floral; anteras 1,3-1,8 $\mathrm{mm}$ compr. Ovário $2 \mathrm{~mm}$ compr. compr., ovóide, tomentoso; estiletes 2,5-7 mm compr. em flores longistilas, glabros, estigmas ramosos. Cápsulas ca. $10 \mathrm{~mm}$ diâm., verrucosas, tomentosas. Sementes ca. 1,7 mm compr., obovóides, ligeiramente curvas, malhas do tégmen ligeiramente proeminentes; arilo 1,7-2 mm compr., lacerado.

Material examinado: Jucurutu, Saco de São Vicente, 25.VI.1980, fl. e fr., O.F. Oliveira et al. 1197 (MOSS). Serra Negra do Norte, Serra Negra, 11.II.1981, fl. e fr., O.F. Oliveira et al 1576 (MOSS).

Turnera chamaedrifolia ocorre somente no Brasil, dispersa-se por todos estados do Nordeste e parte do Sudeste (Minas Gerais e Rio de Janeiro) (Arbo 2012). No estado do Rio Grande do Norte, foi encontrada na caatinga. Coletada com flores e frutos em fevereiro e junho, crescendo em solos arenosos e argilosos, ou em leitos de rios. Foram analisados apenas indivíduos longistilos, porém Arbo (2000) também menciona indivíduos brevistilos e homostilos para a espécie. Enquadrase na categoria "Não Ameaçada de Extinção" (LC).

Turnera chamaedrifolia é caracterizada, pelas suas folhas aromáticas, por vezes viscosas, com abundantes tricomas capitado-estipitados, bem como pela coloração creme de suas flores, mesmo após herborização.

2.5. Turnera diffusa Willd. ex Schult. Syst. Veg., ed. 15 bis [Roemer \& Schultes] 6: 679. 1820

Fig. 2k-m

Subarbustos, ca. 1,1 m alt.; ramos escuros, pubescentes a estrigosos, tricomas tectores simples, ondulados ou lisos, e tricomas glandulares capitadosésseis; cicatrizes foliares proeminentes. Folhas cartáceas, adensadas no ápice de braquiblastos; pecíolo de 0-3 mm compr.; estípulas 0,5-1 $\mathrm{mm}$, subuladas; lâmina 8-20 × 2-4 mm, face abaxial esbranquiçada, ápice obtuso, margem crenadoserreada, revoluta, base cuneada a atenuada; nectários extraflorais ausentes. Inflorescências unifloras, no ápice de braquiblastos. Flores heterostilas; pedicelo $0-0,5 \mathrm{~mm}$ compr.; brácteas 2-5 mm compr., subuladas. Tubo calicino $4-8 \mathrm{~mm}$ compr., lacínios 3-4 mm compr., externamente pubescentes. Corola 5-9 mm compr., amareloviva. Estames glabros; filetes 3,3-4 mm compr., em flores brevistilas, ca. 3,5 mm compr. em flores longistilas; anteras ca. $0,7 \mathrm{~mm}$ compr., retas. Ovário 1-1,4 mm compr., tomentoso; estiletes 2-2,5 mm compr. em flores brevistilas, $4-5 \mathrm{~mm}$ 
compr. em flores longistilas, pubescentes, estigmas fimbriados. Cápsulas 2-3 mm compr., ovóides, verrucosas, revestidas por restos de perianto. Sementes ca. $2 \mathrm{~mm}$ compr., obovoides, curvas, malhas do tégmen não proeminentes; arilo 1,2 mm compr.

Material examinado: Jandaíra, Estação Ecológica de Terras Secas, 13.V.1986, S.H. Vasconcelos 15 (MOSS). Macau, entre Macau e a RDS Ponta do Tubarão, 27.VI.2009, fl. e fr., D.N.N. Souza et al. 41 (UERN). Mossoró, Serra do Carmo, 10.IV.1979, M.R. Vodicka 18 (MOSS). Natal, Parque das Dunas, 10.XI.1980, fl. e fr., A. Trindade 231 (UFRN). São Miguel do Gostoso, Reduto, 6.VII.2007, G.B.C. Paterno \& M.I.B. Loiola 160 (UFRN). Touros, Tapera, 08.VIII.1981, O.F. Oliveira et al. 1948 (MOSS). Vera Cruz, Sítio Araçá I, 27.XI. 1994, J.O. Freire 10 (MOSS).

Turnera diffusa apresenta área de distribuição disjunta; ocorre nos Estados Unidos (Texas), México e Antilhas. No Brasil, é descrita para os estados da Piauí, Ceará, Rio Grande do Norte, Paraíba, Pernambuco, Bahia e Minas Gerais (Arbo 2000, 2012).

São reconhecidas duas variedades para a espécie: T. diffusa Willd. ex Schult. var. diffusa, com ampla distribuição nas Américas, e T. diffusa Willd. ex Schult. var. aphrodisiaca (Ward) Urb., restrita ao hemisfério norte no México, América Central, Cuba e Haití (Arbo 2000). Na área de estudo, foi encontrada a variedade típica. Cresce na Caatinga aberta, floresce e frutifica durante a maior parte do ano. Enquadra-se na categoria "Não Ameaçada de Extinção" (LC). A espécie se assemelha com $T$. calyptrocarpa, pode ser facilmente diferenciada desta última pelas pétalas amarelo-vivo, brácteas subuladas e sementes com malhas do tégmen não proeminentes.

2.6. Turnera melochioides Cambess, F1. bras. Merid. (A. St.-Hil.). ii: 219. $1883 . \quad$ Fig. 3a-b

Ervas, ca. $40 \mathrm{~cm}$ alt.; hirsutas a tomentosas, tricomas tectores simples e longos lisos ou ondulados; sem lenticelas. Folhas papiráceas; pecíolo 1-7 mm compr.; estípulas inconspícuas; lâmina $11-30 \times 2-5 \mathrm{~mm}$, elíptico-lanceolada a lanceolada, ápice agudo a obtuso, margem serreado-crenada, discretamente revoluta, base atenuada a cuneada; nectários ca. 0,3 mm diâm. Inflorescências unifloras, epifilas, congestas, capituliformes. Flores heterostilas; pedúnculo ca. $2 \mathrm{~mm}$ compr., soldado ao pecíolo; bractéolas 1,1-3 mm compr., subuladas a lanceoladas. Tubo calicino 3-9 mm compr., lacínios ca. $7 \mathrm{~mm}$ compr., externamente hirsutos, múcron apical ca. 0,7 mm compr. Corola ca. 17 mm compr., amarela. Estames pubescentes na base; filetes 6-7 mm compr., em flores brevistilas; anteras ca. $1 \mathrm{~mm}$ compr., ápice recurvado. Ovário 3,5-4,5 mm compr., ovóide, tomentoso; estiletes ca. 3,5 mm compr. em flores brevistilas, estigmas fimbriados. Cápsulas ca. 2 mm diâm., ovóides, tomentosas, lisas. Sementes 1,7-2 mm compr., obovoides, curvas; malhas do tégmen não proeminentes, testa lisa a papilosa; arilo 1,5-2 $\mathrm{mm}$ compr.

Material examinado: Canguaretama, acesso a Barra do Cunhaú, 7.VII.2006, fl. e fr., R.C. Oliveira et al. 1739 (MOSS). Mossoró, Serra do Carmo, 30.IV.1979, fl. e fr., O.F. Oliveira 677 (MOSS). Natal, Parque das Dunas, 21.IV.2010, fl. e fr., J.G. Jardim 5649 (UFRN). Parnamirim, EMPARN (Mata do Jiquí), 29.XI.2007, fl. e fr., J.E.D. Barbosa et al. 07 (UFRN). São Miguel do Gostoso, Reduto, 6.VII.2007, fl. e fr., G.B.C. Paterno \& M.I.B. Loiola 165 (UFRN).

Arbo (2008) considera quatro variedades para Turnera melochoides. Neste estudo foi analisada T. melochioides var. latifolia Urb. Ocorre somente na Bolívia e no Brasil, nos estados do Norte (Pará, Amazonas), Nordeste (Maranhão, Piauí, Ceará, Rio Grande do Norte, Pernambuco, Bahia, Sergipe), Centro-Oeste (Mato Grosso) (Arbo 2012). Encontrada na caatinga e restinga, florescendo e frutificando em abril, julho e novembro. Foram analisados apenas indivíduos brevistilos, porém Arbo (2008) também menciona indivíduos longistilos para a espécie. Enquadra-se na categoria "Não Ameaçada de Extinção" (LC).

Esta espécie é facilmente reconhecida por apresentar folhas elíptico-lanceoladas, inflorescências congestas, capituliformes e frutos lisos e tomentosos. Pode ser confundida com $T$. pumilea L., da qual é diferenciada pelas flores heterostilas.

2.7. Turnera pumilea L., Syst. Nat., ed. 10. 2: 965. 1759.

Fig. 3c-e

Ervas, ca. $20 \mathrm{~cm}$ alt.; tomentosas ou hirsutas, tricomas tectores simples longos e/ou ondulados; sem lenticelas. Folhas papiráceas, adensadas no ápice dos ramos; sem estípulas; pecíolo 3-11 mm compr.; lâmina 11-44 × 9-16 mm, ovada a ovado-elíptica, ápice agudo, margem serreado-crenada, base atenuada a cuneada; nectários extraflorais, $0,2-0,5 \mathrm{~mm}$ diâm. Inflorescências unifloras, epifilas, congestas. Flores homostilas; brácteolas $3-5 \mathrm{~mm}$ compr., lineares. Tubo calicino $5 \mathrm{~mm}$ compr., lacínios $2 \mathrm{~mm}$ compr., externamente glabros ou com raros tricomas simples, 

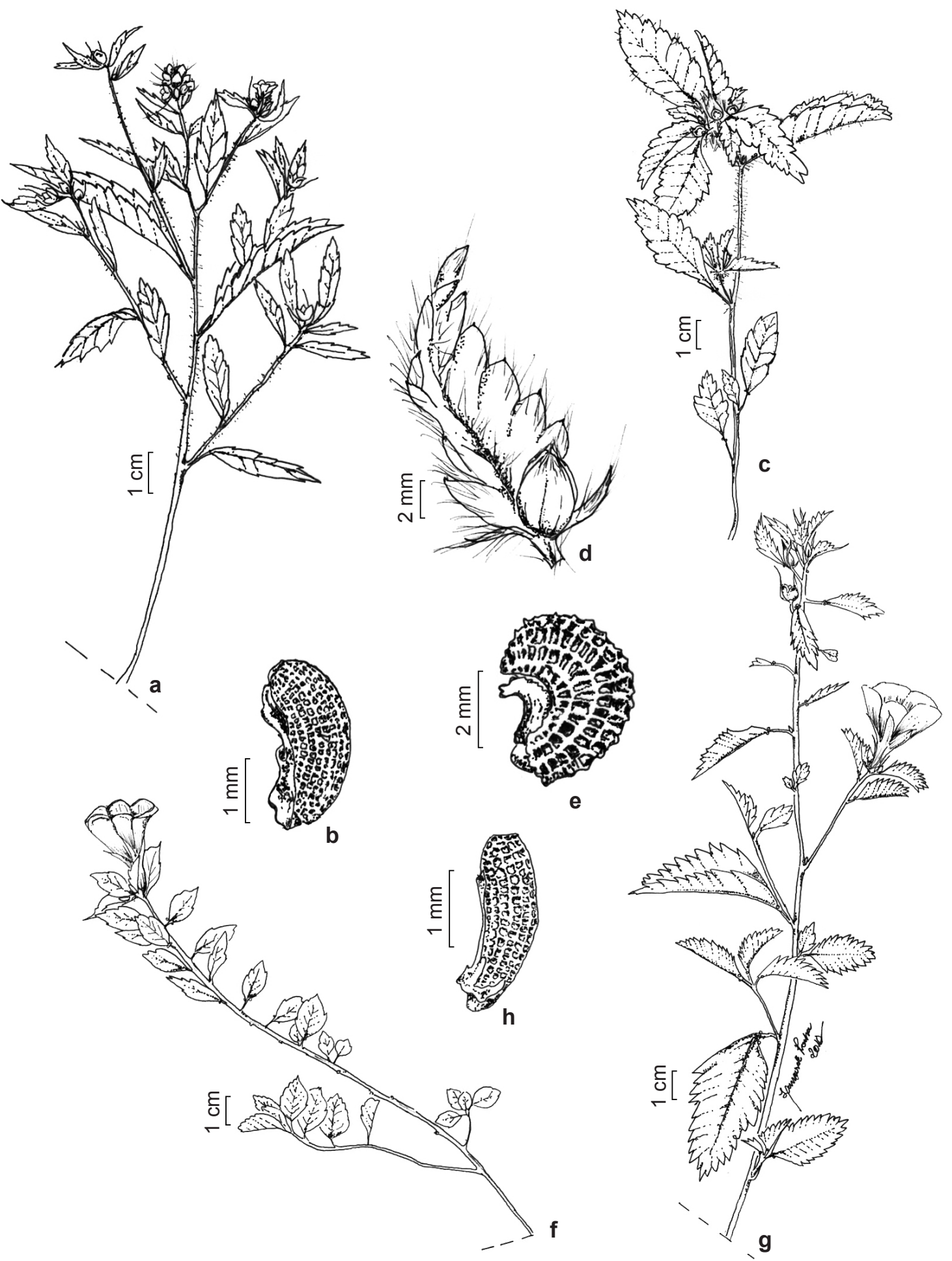

Figura 3 - a-b. Turnera melochioides (G.B.C. Paterno \& M.I.B. Loiola 165) - a. ramo florífero; b. semente. c-e. T. pumilea (L.N.G. Rocha 122) - c. ramo frutífero; d. fruto; e. semente. f. T. scabra (O.F. Oliveira 1331) - ramo florífero. g-h. T. subulata (L.N.G. Rocha 119) - g. ramo florífero; h. semente.

Figure 3 - a-b. Turnera melochioides (G.B.C. Paterno \& M.I.B. Loiola 165) - a. fertile branch; b. seed. c-e. T. pumilea (L.N.G. Rocha $122)$ - a. fruit branch; d. fruit; e. seed. f. T. scabra (O.F. Oliveira 1330) - fertile branch. g-h. T. subulata (L.N.G. Rocha 156) - g. fertile branch; h. seed. 
múcron apical ca. 0,5 mm compr. Corola ca. $7 \mathrm{~mm}$ compr., alaranjada, fauce amarelo vivo; múcron apical ca. 0,5 mm compr. Estames glabros; filetes ca. $6 \mathrm{~mm}$ compr.; anteras ca. $1 \mathrm{~mm}$ compr., retas. Ovário ca. 1,7 mm compr., ovóide, porção basal glabra, ápice pubescente; estiletes $0,6 \mathrm{~mm}$ compr., glabros, estigmas fimbriados. Cápsulas 2-3,5 mm diâm., ovoides, lisas; valvas com porção basal glabra, pubescente no ápice. Sementes ca. $2 \mathrm{~mm}$ compr., obovoides, curvas, tégmen com malhas proeminentes, testa puberulenta; arilo ca. $1 \mathrm{~mm}$ compr.

Material examinado: Currais Novos, Fazenda Bela Vista, 9.VI. 1981, fl. e fr., G.F.C. Lima 090 (MOSS). Jucurutú, RPPN Stöessel de Brito, 28.III.2009, fl. e fr., L.N.G. Rocha et al. 122 (UERN). São Tomé, Serra da Gameleira, 14.IV.1980, fr., O.F.Oliveira et al. 292 (MOSS).

Turnera pumilea ocorre desde o México e Caribe até o norte da Argentina (Arbo 2008). No Brasil ocorre no Norte (Roraima, Pará, Tocantins), Nordeste (Maranhão, Piauí, Ceará, Rio Grande do Norte, Paraíba, Pernambuco, Bahia, Sergipe), Centro-Oeste (Mato Grosso, Goiás, Mato Grosso do Sul), Sudeste (Minas Gerais, Rio de Janeiro) (Arbo 2012). São reconhecidas duas variedades para a espécie, var. pumilea e var. piauhyensis Urb., no estado do Rio Grande do Norte foi encontrada a variedade típica. Cresce na caatinga. Coletada com flores e frutos em março, abril e junho. Enquadra-se na categoria "Não Ameaçada de Extinção" (LC).

Esta espécie é facilmente reconhecida pela disposição das folhas, em rosetas apicais, flores homostilas e frutos glabros na base, com ápice das valvas tomentosos.

2.8. Turnera scabra Millsp., Publ. Field Columb. Mus., Bot. Ser. 2: 77. 1900.

Fig. $3 f$

Erva, ca. $40 \mathrm{~cm}$ alt., prostrada; estrigosa a tomentosa, tricomas simples; cicatrizes foliares proeminentes. Folhas papiráceas; pecíolo de 1-3 mm compr.; estípulas reduzidas a coléteres; lâmina 6-10 × 5-8 cm, elíptica, ovado-elíptica, ápice agudo ou raro obtuso, margem crenadoserreada, base atenuada; nectários extraflorais, 0,5-0,6 mm diâm., discóides. Inflorescências unifloras, epífilas. Flores heterostilas; pedúnculo ca. $3 \mathrm{~mm}$, adnato ao pecíolo; bractéolas $0,8-4$ $\mathrm{mm}$ compr., subuladas. Tubo calicino 5-6 mm compr., campanulado, lacínios ca. $6 \mathrm{~mm}$ compr., externamente tomentosos; múcron ca. $1 \mathrm{~mm}$ compr. Corola ca. 2,9 mm compr., branca, fauce amareloviva. Estames glabros; filetes ca. 1,1 mm compr. em flores longistilas, ca. $8 \mathrm{~mm}$ compr. em flores brevistilas, margens adnatas pela face adaxial ao tubo floral formando sacos nectaríferos; anteras ca. $2 \mathrm{~mm}$ compr., retas. Ovário $4 \mathrm{~mm}$ compr., ovóide, tomentoso, estiletes ca. $2 \mathrm{~mm}$ compr. em flores longistilas, ca. 1,1 mm compr. em flores brevistilas, pubescentes, estigmas ramosos. Cápsulas ca. $4 \mathrm{~mm}$ diâm., ovóides, verrucosas, tomentosas. Sementes 2,1-2,9 mm compr., obovoides, curvas, malhas do tégmen não proeminentes; arilo mais curto ou igual à semente.

Material selecionado: Natal, 30.IX.1980, f1. e fr., O.F. Oliveira et al. 1331 (MOSS).

Esta espécie se dispersa desde o Sul do México, América Central, nas ilhas do Caribe, Colômbia, Venezuela e Guiana e, no Brasil, onde ocorre no Norte (Roraima, Amapá, Pará, Amazonas, Acre), Nordeste (Maranhão, Piauí, Ceará, Rio Grande do Norte, Pernambuco, Bahia, Alagoas), Sudeste (Espírito Santo) (Arbo 2005, 2012). Associa-se às vegetações de caatinga e restinga, preferencialmente sobre solos arenosos bem drenados. Coletada com flores e frutos nos meses de agosto e setembro. Enquadra-se na categoria "Não Ameaçada de Extinção" (LC).

Turnera scabra pertence ao complexo de $T$. ulmifolia à qual é morfologicamente assemelhada, mas pode ser diferenciada desta especialmente por apresentar flores heterostilas (Arbo 2005). As informações referentes às sementes foram extraídas de Arbo (2005).

2.9. Turnera subulata $\mathrm{Sm}$. in Rees, A. Cyclop. 36 (2). 1817.

Fig. 3g-h

Ervas ou subarbustos, ca. 0,3-1,2 m alt.; pubescentes a estrigosos, tricomas lisos ou ondulados, principalmente nos ramos jovens. Folhas papiráceas; pecíolo 1-16 mm compr.; estípulas 0,5 $1 \mathrm{~mm}$ compr., às vezes reduzidas a coléteres; lâmina $1,1-12 \times 0,3-5 \mathrm{~cm}$, ovada, obovada a lanceolada, ápice agudo a obtuso, margem serreada a serreadocrenada, base atenuada; nectários extraflorais 2(-4), ca. $1 \mathrm{~mm}$ diâm., discóides. Inflorescências unifloras, epífilas, por vezes congestas. Flores heterostilas; pedicelo 3-7 $\mathrm{mm}$ compr., adnato parcial ou totalmente ao pecíolo; brácteas 1-15 $\mathrm{mm}$ compr., subuladas. Tubo calicino $4-6 \mathrm{~mm}$ compr., campanulado, lacínios 4-11 mm compr., externamente tomentosos, múcron apical 1-4 mm compr. Corola 1,2-3 cm compr., brancas, fauce preto-azulada. Estames glabros; filetes $6-7 \mathrm{~mm}$ compr. em flores longistilas, ca. $13 \mathrm{~mm}$ compr. em flores brevistilas, margens adnatas pela face adaxial ao tubo floral formando sacos nectaríferos; anteras 3-4 mm compr., retas. Ovário ca. $2 \mathrm{~mm}$ 
compr., ovóide, tomentoso; estiletes ca. $11 \mathrm{~mm}$ compr. em flores longistilas, $8-9 \mathrm{~mm}$ compr. em flores brevistilas, estigmas fimbriados. Cápsulas 2,5-7 mm diâm., ovóides, verrucosas, tomentosas. Sementes 2,7-3 mm compr., obovoides, curvas, malhas do tégmen não proeminentes; arilo ca. 2 mm compr.

Material selecionado: Apodi, margem de açude, 12.II.2008, fl. e fr., J.I.M. Melo 677 (UERN). Grossos, Salina Salmar, 28.VI.2007, fl. e fr., A.A. Roque 165 (UFRN). Jucurutú, RPPN Stöessel de Brito, 28.III.2009, fl. e fr., L.N.G. Rocha 119 (UERN). Luis Gomes, 13.VI.2008, fl. e fr., R.G.V. Camacho et al. 140 (UERN). Macaíba, 16.VIII. 1993, M.A.M. Dantas 02 (MOSS). Macau, RDS Estadual Ponta do Tubarão, Comunidade Sertãozinho, 1.VII. 2008, fl. e fr., L.G. Lima 45 (UFRN). Martins, mirante, 15.X.2009, fl. e fr., R.G.V. Camacho et al. 249 (UERN). Mossoró, margem da BR 110, 19.III.2009, fl. e fr., L.N.G. Rocha 66 (UERN). Natal, Parque das Dunas, 25.VI.2007, fl. e fr., V.R.R. Sena et al. 160 (UFRN). Nísia Floresta, dunas da Praia de Búzios, 20.III.2008, fl. e fr., A.C.P. Oliveira 799 (UFRN). Parnamirim, EMPARN Mata do Jiquí, 28.XI.2007, fl. e fr., M.L. Mota et al. 13 (UFRN). Serra Negra do Norte, Estação Ecológica do Seridó, 1.V.2005, fl. e fr., R.T. Queiroz 270 (UFRN). Touros, próximo a Santa Luzia, 11.VIII.1981, fl., O.F. Oliveira et al. 2007 (MOSS). Viçosa, 21.X. 2007, fl. e fr., J.I.M. Melo et al. 636 (UERN).

Esta espécie distribui-se desde o Panamá, Colômbia, Venezuela, Guiana Francesa, Equador, até o norte da Bolívia. Foi introduzida na Ásia, Japão, Sri Lanka, Seychelles, Madagascar e Índia (Arbo 2005). No Brasil, ocorre na maioria dos estados, excetuando-se Acre e Roraima (no Norte) e todos aqueles da Região Sul (Arbo 2012). No estado do Rio Grande do Norte se comporta como ruderal, associa-se a ambientes de caatinga e restinga. Florescendo e frutificando durante o ano inteiro. Enquadra-se na categoria "Não Ameaçada de Extinção" (LC).

A espécie é morfologicamente relacionada à Turnera scabra, sendo prontamente diferenciada desta última por apresentar flores com fauce enegrecida. Arbo (2005) ainda adota, entre outros caracteres, o formato das sementes como atributo diagnóstico; T. subulata possui sementes curvas enquanto T. scabra apresenta sementes retas.

\section{Agradecimentos}

Os autores agradecem à Prof ${ }^{\mathrm{a}}$. Dr ${ }^{\mathrm{a}}$. Suely Maria Leal de Castro, do Departamento de Química (UERN), pela liberação do veículo para a realização das expedições de coleta. Aos curadores dos herbários do estado do Rio Grande do Norte (MOSS, UFRN), que possibilitaram o estudo das coleções. Aos colegas Diego Nathan, Elizabeth Bezerra e Noelia Ferreira, pelo auxílio prestado principalmente durante a realização dos trabalhos no campo.

\section{Referências}

Agra, M.F.; Kiriaki, N.S.; Costa-Silva, R. \& GomesCosta, G. 2009. Turneraceae. In: Alves, M.; Araújo, M.F.; Maciel, J.R. \& Martins S. (eds.). Flora de Mirandiba. Associação Plantas do Nordeste, Recife. Pp. 344-347.

Angiosperm Phylogeny Group. 2009. An update of the Angiosperm Phylogeny Group classification for the orders and families of flowering plants: APG III. Botanical Journal of the Linnean Society 161: 105-121.

Arbo, M.M. 1995a. Turneraceae. Parte I. Piriqueta. Flora Neotropica 67: 1-156.

Arbo, M.M. 1995b. Turneraceae. In: Stannard, B.L. (ed.). Flora of the Pico das Almas, Bahia-Brasil. Royal Botanic Gardens, Kew. Pp. 615-619.

Arbo, M.M. 1997. Estudios sistemáticos en Turnera (Turneraceae). I, Series Salicifoliae y Stenodictyae. Bonplandia 9: 151-208.

Arbo, M.M. 2000. Estudios sistemáticos en Turnera (Turneraceae). II. Series Annulares, Capitatae, Microphyllae y Papilliferae. Bonplandia 10:1-82.

Arbo, M.M. 2005. Estudios sistemáticos en Turnera (Turneraceae). III. Series Anomalae y Turnera. Bonplandia 14: 115-318.

Arbo, M.M. 2006a. Flora de Grão-Mogol, Minas Gerais: Turneraceae. Boletim de Botânica da Universidade de São Paulo 21: 1-24.

Arbo, M.M. 2006b. Turneraceae. In: Barbosa, M.R.V.; Sothers, C.; Mayo, S.; Gamarra-Rojas, C.F.L. \& Mesquita, A.C. (eds.). Checklist das plantas do nordeste Brasileiro: Angiospermas e Gymnospermas. Ministério da Ciência e Tecnologia, Brasília. Pp. 150-151.

Arbo, M.M. 2007. Turneraceae. In: Kubitzki, K.; Rhower, J.B. \& Bittrich, V. (eds.). The families and genera of vascular plants. Vol. 9. Springer-Verlag. Pp. 458-466.

Arbo, M.M. 2008. Estudios sistemáticos en Turnera (Turneraceae). IV. Series Leiocarpae, Conciliatae y Sessilifoliae. Bonplandia 17: 107-334.

Arbo, M.M. 2009. Turneraceae. In: Cavalcanti, T.B. \& Batista, M.F. (orgs.). Flora do Distrito Federal, Brasil. Vol. 7. Embrapa Recursos Genéticos e Biotecnologia, Brasília. Pp. 285-312.

Arbo, M.M. 2012. Turneraceae. In: Forzza, R.C. et al. (eds.). Lista de espécies da flora do Brasil. Jardim Botânico do Rio de Janeiro, Rio de Janeiro. Disponível em <http://floradobrasil.jbrj.gov. br/2012/FB014980>. Acesso em 17 Jun 2012. 
Arbo, M.M. \& Mazza, S.M. 2011. The major diversity centre for neotropical Turneraceae. Systematics and Biodiversity 9: 203-210.

Arbo, M.M. \& Silva, P.H. 2005. Turneraceae. In: Wanderley, M.G.L.; Shepherd, G.J.; Melhem, T.S. \& Giulietti, A.M. (coords.). Flora fanerogâmica do estado de São Paulo. Vol. 4. Fapesp, Rima, São Paulo. Pp. 351-359.

Braga, R. 2001. Chanana. In: Plantas do nordeste especialmente do Ceará. Fundação Guimarães Duque, Mossoró. 175p.

Brumitt, R.K. \& Powell, C.E. 1992. Authors of plant names. Royal Botanic Gardens, Kew. 732p.

Chase, M.W.; Zmartzty, S.; Lledó, M.D.; Wurdack, K.J.; Swensen, S.M. \& Fay, M.F. 2002. When in doubt, put it in Flacourtiaceae: a molecular phylogenetic analysis based on plastid rbcL DNA sequences. Kew Bulletin 57: 141-181.

Cronquist, A. 1981. An integrated system of classification of flowering plants. The New York Botanical Garden, Columbia University Press, New York. $1262 p$.

Dahlgren, R.M.T. 1980. A revised system of classification of the angiosperms. Botanical Journal of the Linnean Society 80: 91-124.

Gonzalez, A.M. \& Arbo, M.M. 2004. Trichome complement of Turnera and Piriqueta (Turneraceae). Botanical Journal of the Linnean Society 144: 85-97.

Harris, J.G. \& Harris, M. W. 1994. Plant identification terminology: an illustrated glossary. Spring Lake Publishing, Utah. 189p.

Hickey, L.J. 1973. Classification of the architecture of dicotyledonous leaves. American Journal of Botany 60: 17-33.

Hutchinson, J. 1973. The families of the flowering plants. $3^{\text {rd }}$ ed. Clarendon Press, Oxford. 968p.

IDEMA. Instituto de Desenvolvimento Sustentável do e Meio Ambiente do Rio Grande do Norte. Anuário
Estatístico 2008. Disponível em http://www. idema.rn.gov.br/contentproducao/aplicacao/idema/ anuario/enviados/anuario_estatistico.asp. Acesso em 22 Fev 2010.

IUCN. 2001. International Union for Conservation of Nature and Natural Resources Red List Categories and Criteria: Version 3.1. IUCN Species Survival Commission. IUCN, Gland and Cambridge. $\mathrm{ii}+30 \mathrm{p}$.

IUCN. 2003. Guidelines for application of IUCN red list criteria at regional levels: Version 3.0. IUCN Species Survival Commission. IUCN, Gland and Cambridge. ii $+26 \mathrm{p}$.

Moura, C.A.F. 1975. Turneráceas. In: Reitz, R. (ed.). Flora Ilustrada Catarinense. Parte I, fasc. Tur. Herbário ‘Barbosa Rodrigues', Itajaí. 13p.

Payne, W.W. 1978. A glossary of plant hair terminology. Brittonia 30: 239-255.

Radford, A.E.; Dickison, W.C.; Massey, J.R. \& Bell, C.R. 1974. Vascular plant systematics. Harper \& Row Publishers, New York. 891p.

SUDENE. 1971. Levantamento exploratórioReconhecimento de solos do Rio Grande do Norte. Superintendência para o Desenvolvimento do Nordeste, Recife. 531p.

Thiers, B. 2009 [continuously updated]. Index Herbariorum: A global directory of public herbaria and associated staff. New York Botanical Garden's Virtual Herbarium. Disponível em <http:// sweetgum.nybg.org/ih>. Acesso em 23 Mar 2011.

Urban, I. 1883a. Monographie des familie Turneraceen. Vol 2. Jahrb. Königl. Bol. Gart. Berlin. Pp. 1-152.

Thulin, M.; Razafimandimbison, S.G.; Chafe, P.; Heidari, N. Kool, A. \& Shore, J.S. 2012. Phylogeny of the Turneraceae clade (Passifloraceae s.l.): TransAtlantic disjunctions and two new genera in Africa. Taxon 61: 308-323.

Urban, I. 1883b. Turneraceae. In: Martius, C.F.P.; Eichler, A.G. \& Urban, I. (eds.). Flora brasiliensis. Monachii et Lipsiae, R. Oldenbourg. Vol. 13. Pp. 86-170. 
